\title{
32. CRETACEOUS PLANKTONIC FORAMINIFERA FROM THE EASTERN INDIAN OCEAN
}

\author{
René Herb, Geological Institute, University of Berne, Switzerland
}

\begin{abstract}
Cretaceous planktonic foraminifera occur at four sites drilled on Leg 26: on the Broken Ridge (Site 255), in the Wharton Basin (Sites 256 and 257), and on the Naturaliste Plateau (Site 258). In the Wharton Basin only assemblages of Albian age were found. These differ from each other in preservation and in their specific composition. The sequence on the Naturaliste Plateau ranges from upper Albian to Santonian. Rich and well-preserved faunas were found in the Albian, Cenomanian, Coniacian, and Santonian. The main features of all Cretaceous assemblages from this part of the Indian Ocean are the low diversity and the predominance of nonkeeled forms of the genera Hedbergella, Globigerinelloides, Whiteinella, and Archaeoglobigerina. This indicates a cool paleoenvironment for this area during the Cretaceous. Range charts for Sites 257 and 258 are given, and most of the species are discussed in the systematic part of this report.
\end{abstract}

\section{INTRODUCTION}

During Leg 26 Cretaceous planktonic foraminifera were recorded at four different sites in the eastern part of the Indian Ocean: at Sites 255 (Broken Ridge), 256 and 257 (Wharton Basin), and 258 (Naturaliste Plateau). The lithology of the Cretaceous sequences in these three areas differs considerably from one area to another. (See Figure 1.) At the Broken Ridge site indurated and tilted limestone with intercalating chert was penetrated. Foraminifera could not be isolated from these hard rocks and were studied in thin section.

The assemblages in the Wharton Basin occur in brown detrital clay which was deposited near the lysocline. Many tests show dissolution effects. Planktonic foraminifera occur only in the Albian part of these two sites.

Site 258 on the Naturaliste Plateau is the only one where, over a relatively long stratigraphic interval, ranging from the Albian to the Santonian, good planktonic assemblages were found. The present description and discussion is therefore mainly based on the study of material from this site.

The assemblages found are of particular interest since, so far, relatively few data have been available from the southern hemisphere. However, a number of important papers have been published on Cretaceous planktonic foraminifera from Australia (e.g., Edgell, 1957; Belford, 1960; and Belford and Scheibnerova, 1971); they allow a correlation of our sites with the onshore Cretaceous of Western Australia. A Turonian faunule from the Naturaliste Plateau near Site 258 has been described by Burckle, Saito, and Ewing (1967).

\section{PLANKTONIC FORAMINIFERAL ASSEMBLAGES FROM SITES 255-258}

Site 255

Sixteen thin sections of limestone and chert from the following samples were studied: Sample 8, CC; Sample
9-1, 116-118 cm; Sample 9, CC; Sample 10-1, $72-74 \mathrm{~cm}$; Sample 10-1, 74-76 cm; Sample 10, CC; Sample 11, CC. Most of the limestone, and in part also the chert, contains planktonic foraminifera in great abundance. Practically all of them are small globigerine-shaped forms and planispiral tests belonging to the genus Globigerinelloides, which cannot be specifically identified. Rare oblique sections of double-keeled globotruncanid forms may possibly be attributed to Globotruncana arca or related forms, which suggests a Santonian to Campanian age of this limestone. This corresponds with the Santonian age determined by nannoplankton.

Apart from planktonic foraminifera, most of the samples contain numerous benthonic foraminifera, fragments of Inoceramus, including abundant isolated calcite prisms of the ostrakum, as well as fragments of other pelecypods and crinoids. Some of the samples contain glauconite, which frequently fills the tests of radiolarians.

Much of the limestone is partly silicified and fossil remains, particularly the tests of foraminifera and the prisms of Inoceramus may be partially or totally silicified. A section through the boundary between the siliceous limestone and chert shows that this boundary may cut across foraminiferal tests, which clearly demonstrates that the silicification is postdepositional.

\section{Site 256}

At this site Cretaceous planktonic foraminifera occur only within the 2 meters of sediment immediately above the basalt. They were recorded in Sample 8-6, 115-119 $\mathrm{cm}$; Sample 8, CC; and Sample 9-1,120-122 cm. The main feature of these assemblages is the very small size of the specimens, the rather poor preservation (the tests being etched and recrystallized), and their virtually monospecific composition (Plate 1, Figures 1-6). Most of the specimens can be assigned to Hedbergella planispira, but some show transitional features to $H$. 
SITE 255

$31^{\circ} 08^{\prime} \mathrm{S} \quad 93^{\circ} 44^{\prime} \mathrm{E}$

$1144 \mathrm{~m}$

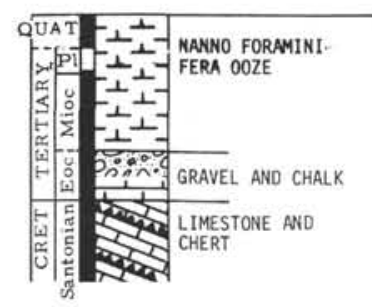

T.D. $108.5 \mathrm{~m}$
SITE 256

$23^{\circ} 28^{\prime} \mathrm{S} 100^{\circ} 47^{\prime} \mathrm{E}$

$5361 \mathrm{~m}$

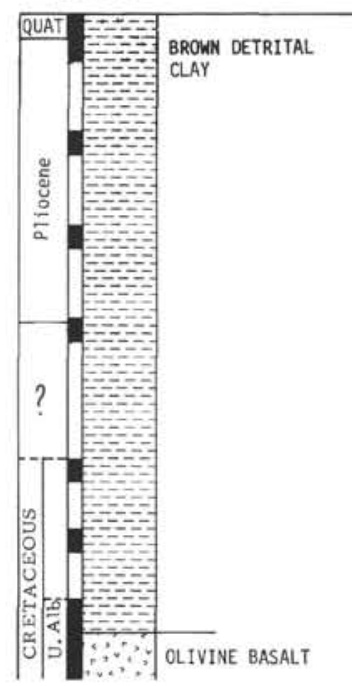

T.D. $270 \mathrm{~m}$
SITE 257

$30^{\circ} 59^{\prime} \mathrm{S} 108^{\circ} 21^{\prime} \mathrm{E}$

5278 a

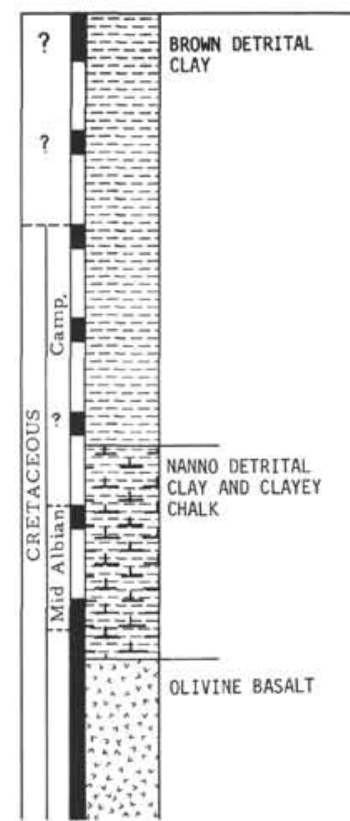

T.D. $326.5 \mathrm{~m}$
SITE 258

$33^{\circ} 48^{\prime}$ S $112^{\circ} 29^{\prime} \mathrm{E}$

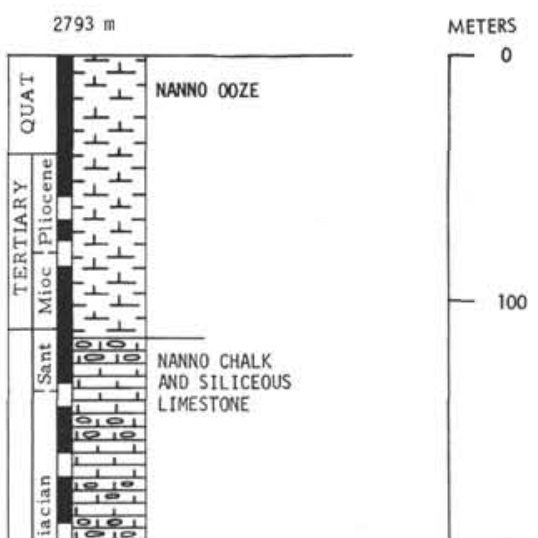

$-200$
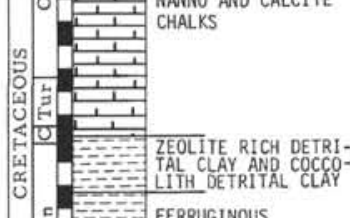

O FERRUGINOUS

DETRITAL CLAYS

要

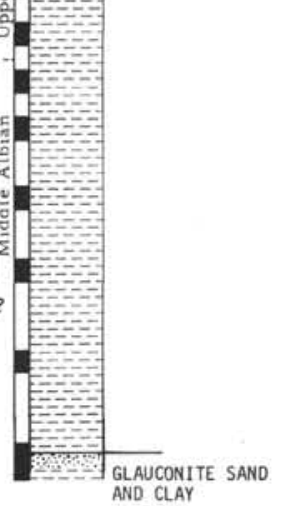

T.D. $525 \mathrm{~m}$

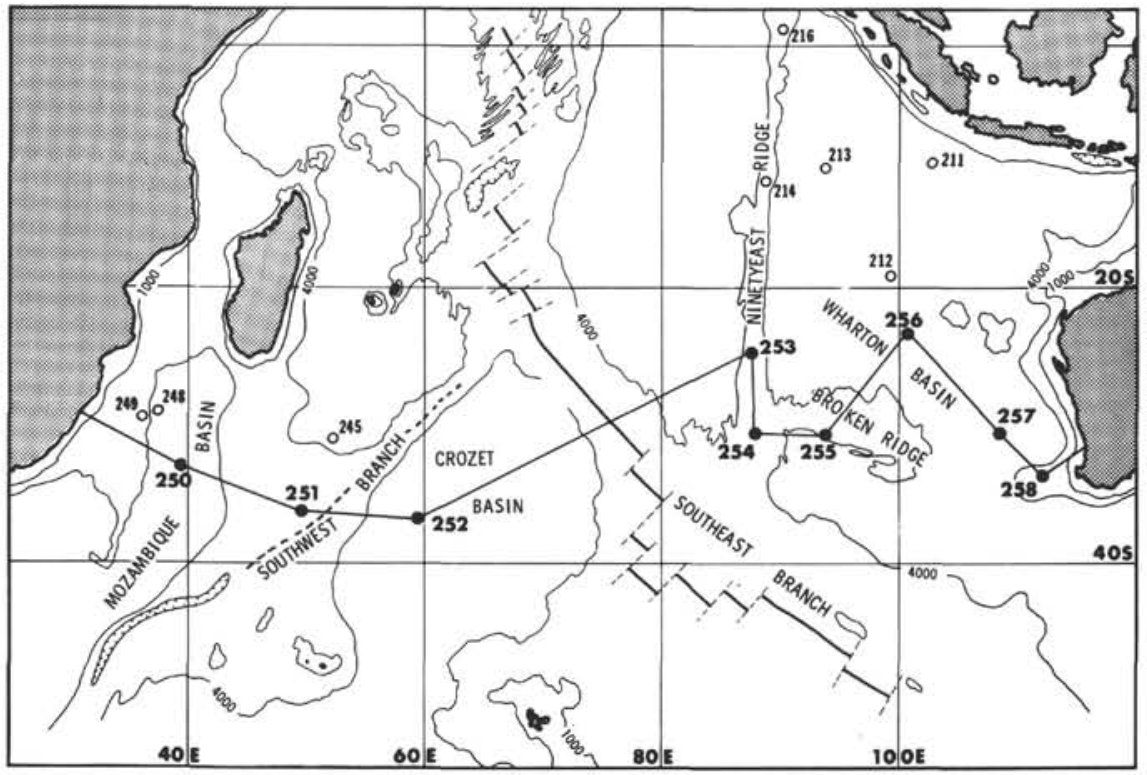

LEG 26 DURBAN-FREMANTLE ISEPT. - OCT. 1972)

Figure 1. Stratigraphic sections of Sites 255-258 and location of sites. Intervals with Cretaceous planktonic foraminifera are. indicated with heavy vertical lines. 
infracretacea. Schackoina cf. cenomana has been found very rarely in Core 9 (Plate 1, Figure 6).

Age: No precise age determination can be given based on these assemblages. Due to the poor preservation, the identification of Schackoina cenomana must remain uncertain. As mentioned below, this species has been found on the Naturaliste Plateau in Cenomanian as well as, although very rarely, in Albian sediments. The fauna of Site 256, however, has more affinities with the Albian of Sites 257 and 258 than with the Cenomanian of Site 258, which supports the Albian age determined by the nannoplankton.

\section{Site 257}

As at Site 256 the occurrence of Cretaceous planktonic foraminifera is restricted to an interval near the base of the sedimentary sequence. An exception must be made for Sample 5-1, 140-142 cm, where, in a thin section of siliceous clay, Globotruncana cf. evelata could be identified. This indicates a possible Campanian age for this level.

In the lower part of the sedimentary sequence planktonic foraminifera occur between Core 7, Section 2, and Core 9 , Section 2, i.e., in an interval of approximately 48 meters. None has been found in the lowermost 8 meters of sediment immediately above the basalt. The abundance and preservation of planktonic foraminifera is best between the base of Core 7 and the upper part of Core 9. The disappearance below this level is abrupt. The occurrence of calcareous microfossils, including benthonic foraminifera and calcispheres (Pithonella), corresponds to a short period of time during the Albian, in which the site was temporarily within or above the lysocline.

Hedbergella planispira is the most frequent foraminiferal species in most of the samples (Plate 2, Figures 5-8). In Cores 8 and 9 it is accompanied by a transitional form to $H$. infracretacea (Plate 2, Figures 14). $H$. aff. sigali is a very small form occurring in Cores 8 and 9 (Plate 1, Figures 7-16). Globigerinelloides caseyi, Ticinella aff. raynaudi raynaudi, and $T$. cf. roberti have been found in Core Catcher 7 .

The preservation of these assemblages is definitely better than at Site 256. Although the tests are fragile and in many samples strongly affected by solution, many specimens show an excellent state of preservation. (See range chart, Figure 2.)

Calcispheres of the genus Pithonella occur in all samples of Cores 7 and 8 , as well as in the upper part of Core 9 , sometimes in great abundance. Since they are present in samples where planktonic foraminifera have already been completely eliminated (upper part of Core 7), it is obvious that their resistance to solution is greater than that of planktonic foraminifera.

Age: As discussed in the Systematics section, those forms from Site 257 which were assigned to the genus Ticinella are characterized by a "primitive" arrangement of the "supplementary" apertures, and they are therefore interpreted to represent an early evolutionary stage in the formation of the genus. This indicates a middle Albian age for these sediments, which corresponds with the age determination given by the nannoplankton.

\section{Site $\mathbf{2 5 8}$}

At this site Cretaceous planktonic foraminifera were found in a stratigraphic interval ranging from the upper Albian to the Santonian. They occur in two major lithologic units:

1) A nanno-chalk sequence with siliceous limestone and chert in the upper part, Turonian-Santonian; and

2) A predominantly argillaceous sequence with ferruginous detrital clay and interbedded zeolite-rich detrital clay and coccolith detrital clay in the lower part, AlbianCenomanian.

The occurrence of planktonic foraminifera is not uninterrupted, however. In the lower unit there is a gap for the greater part of Cores 16 and 17 , most probably due to dissolution below the carbonate compensation depth. Planktonic foraminifera are also missing below Core 20. This again reflects deposition below the carbonate compensation depth for the lowermost part of the drilled sequence. In the range chart of this site (Figure 3), Cores 21-25 were not therefore listed.

The record of planktonic foraminifera is equally sporadic and for the greater part insufficient in most samples of Cores 11-13(Turonian-Coniacian). There are two main reasons for this:

1) Despite its relatively soft aspect, most of the chalk is indurated and can only be partially washed. Ultrasonic treatment has little effect.

2) In most cases, where foraminifera could be isolated, there is only a very restricted assemblage of rather poorly preserved planktonic foraminifera. Examination of the residue has shown that most tests of planktonic forms cannot be isolated from the rock and are dissolved in many cases, probably during diagenetic processes. Benthonic foraminifera could be isolated more frequently and seem to be more resistant.

Well-preserved assemblages of planktonic foraminifera occur mainly in the Albian, particularly in Core 15, and in the upper part of the Coniacian and in the Santonian (Holes 258, Cores 5-10, and 258A, Cores 8 and 9). In the following paragraphs the main features and the ages of these assemblages will be briefly discussed.

\section{Albian-Cenomanian}

Foraminiferal assemblages in the argillaceous sequence are nowhere abundant, but in a number of samples they are excellently preserved.

A lowermost interval, between Core 17, Section 5, and Sample 258-20, CC, shows very restricted assemblages of small-sized forms. Quantitatively sufficient assemblages were recovered only in the larger corecatcher samples. Only a few species were recorded: Hedbergella planispira (see Plate 3, Figures 1-5), the most frequent species, $H$. cf. infracretacea, Globigerinelloides caseyi, and very rare $H$. simplicissima and $H$. delrioensis. This assemblage indicates most probably upper Albian or Vraconnian. However, a middle Albian age for Cores 19 and 20, as determined by the nannoplankton, cannot be excluded.

A number of well-preserved assemblages were recovered in Core 15. Hedbergella planispira is again the most frequent species (see Plate 3, Figures 6-8), but it is now accompanied by numerous and relatively large $H$. simplicissima (Plate 3, Figures 9-13) and $H$. delrioensis 


\begin{tabular}{|c|c|c|c|c|c|c|c|c|c|c|c|c|c|c|c|}
\hline$\frac{8}{<}$ & 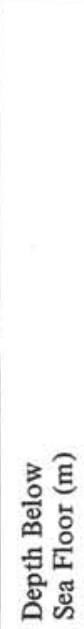 & $\begin{array}{c}\text { Sample } \\
\text { (Interval in } \mathrm{cm} \text { ) }\end{array}$ & 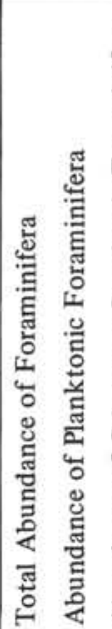 & 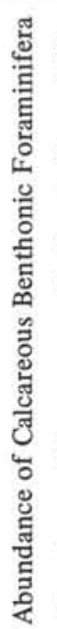 & 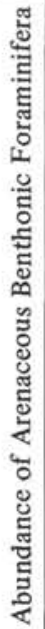 & 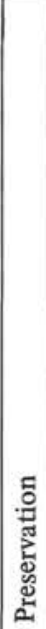 & 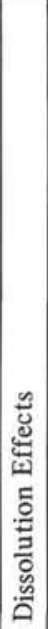 & 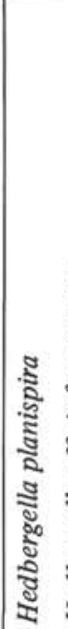 & 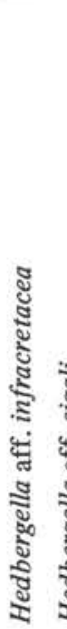 & 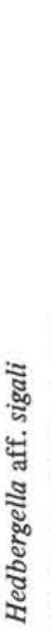 & 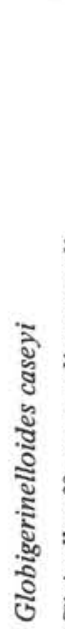 & 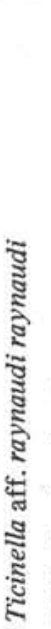 & 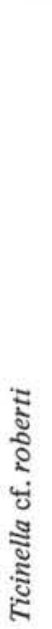 & 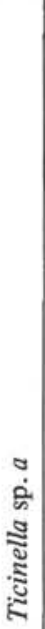 & 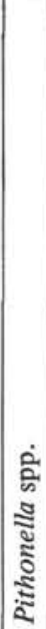 \\
\hline \multirow{4}{*}{ 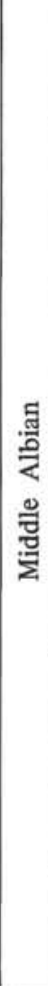 } & 199.5 & $\begin{array}{l}7-1,78-82 \\
7-1,129-134 \\
7-2,40-44 \\
7-2,115-119 \\
7-3,20-25 \\
7-3,120-125 \\
7-4,20-24 \\
7-4,135-140 \\
7-5,20-25 \\
7-5,120-125 \\
7-6,30-25 \\
7-6,120-124 \\
7, \text { CC }\end{array}$ & 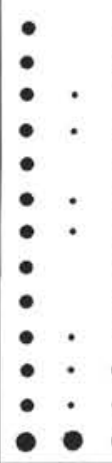 & $\begin{array}{l}\bullet \\
\bullet \\
\bullet \\
\bullet \\
\bullet \\
\bullet \\
\bullet \\
\bullet \\
\bullet \\
\bullet \\
\bullet \\
\bullet \\
-\end{array}$ & $\begin{array}{l}: \\
: \\
: \\
: \\
: \\
: \\
: \\
: \\
: \\
: \\
: \\
-\end{array}$ & $\begin{array}{l}\mathrm{m} \\
\mathrm{m} \\
\mathrm{m} \\
\mathrm{m} \\
\mathrm{m} \\
\mathrm{m} \\
\mathrm{m} \\
\mathrm{m} \\
\mathrm{m} \\
\mathrm{m} \\
\mathrm{m} \\
\mathrm{p} \\
\mathrm{g}\end{array}$ & $\begin{array}{l}3 \\
3 \\
3 \\
3 \\
3 \\
3 \\
3 \\
3 \\
3 \\
3 \\
3 \\
3 \\
1\end{array}$ & $\dot{\dot{\theta}}$ & & & & & ${ }^{\circ}$ & $\cdot$ & $\begin{array}{l}\dot{.} \\
\dot{\bullet} \\
\dot{0} \\
\dot{0} \\
\dot{0} \\
\dot{0} \\
\dot{0}\end{array}$ \\
\hline & $\begin{array}{r}237.5 \\
247.0\end{array}$ & $\begin{array}{l}8-1,66-71 \\
8-1,131-136 \\
8-2,15-20 \\
8-2,132-136 \\
8, \text { CC }\end{array}$ & $\begin{array}{ll}0 & 0 \\
0 & 0 \\
0 & 0 \\
0 & 0 \\
0 & 0\end{array}$ & $\begin{array}{l}\bullet \\
\bullet \\
\bullet \\
\bullet\end{array}$ & $\begin{array}{l}\bullet \\
\bullet \\
\bullet \\
\bullet \\
\bullet\end{array}$ & $\begin{array}{l}\mathrm{g} \\
\mathrm{g} \\
\mathrm{g} \\
\mathrm{g} \\
\mathrm{g}\end{array}$ & $\begin{array}{l}1 \\
2 \\
2 \\
1 \\
1\end{array}$ & • & $\begin{array}{l}- \\
\bullet \\
-1 \\
-1\end{array}$ & $\dot{\bullet}$ & & & & • & : \\
\hline & 247.0 & $\begin{array}{l}9-1,105-109 \\
9-1,133-137 \\
9-2,18-22 \\
9-2,116-120 \\
9-3,39-41 \\
9, \text { CC }\end{array}$ & $\begin{array}{ll}\bullet & 0 \\
\bullet & \bullet \\
\bullet & \bullet \\
\cdot & \\
\cdot & \\
\cdot & \end{array}$ & $\begin{array}{l}\bullet \\
\bullet \\
\bullet\end{array}$ & $\begin{array}{l}\bullet \\
\bullet \\
\bullet \\
\bullet \\
\cdot \\
\cdot\end{array}$ & $\begin{array}{l}\mathrm{m} \\
\mathrm{m} \\
\mathrm{m} \\
\mathrm{p} \\
\mathrm{p} \\
\mathrm{p}\end{array}$ & $\begin{array}{l}2 \\
3 \\
3 \\
4 \\
4 \\
4\end{array}$ & - & $\dot{0}$ & - & & & & & 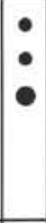 \\
\hline & 256.5 & $\begin{array}{l}10-1,50-51 \\
10-1,78-82 \\
10-1,132-134\end{array}$ & $\dot{\dot{.}}$ & & $\begin{array}{l}\bullet \\
\dot{\bullet} \\
\dot{ }\end{array}$ & $\begin{array}{l}\mathrm{p} \\
\mathrm{p} \\
\mathrm{m}\end{array}$ & $\begin{array}{l}4 \\
4 \\
4\end{array}$ & & & & & & & & \\
\hline
\end{tabular}

Abundance: abundant -common •few -rare;

Preservation: $\mathrm{m}=$ moderate, $\mathrm{p}=$ poor, $\mathrm{g}=$ good;

Dissoultion effects: 1 =slightly affected; 2 =strongly affected; 3 =partially destroyed; $4=$ totally affected

Figure 2. Distribution of Cretaceous planktonic foraminifera at Site 257.

(Plate 3, Figures 15-18). Isolated occurrences of Praeglobotruncana delrioensis (Plate 3, Figure 14) and Schackoina cenomana are interesting to note. The presence of the latter species would indicate a Cenomanian age for this interval. The nannoplankton assemblages, however, have to be placed in the upper Albian (see Thierstein, this volume, Chapter 28) and it seems, therefore, that $S$. cenomana may extend slightly below the Albian/Cenomanian boundary, as was already noted at Site 256 .
The assemblages of Core 14 and Sample 258-13, CC are very similar in composition. Schackoina cenomana is more frequent, and a single fragment of Rotalipora, most probably $R$. reicheli, places this interval in the Cenomanian.

The Albian to Cenomanian assemblages are characterized by a low diversity. In the Albian small Hedbergella are predominant and no representatives of the genus Ticinella, otherwise typical for this stage, could be found. Keeled Rotalipora are absent in the Ceno- 


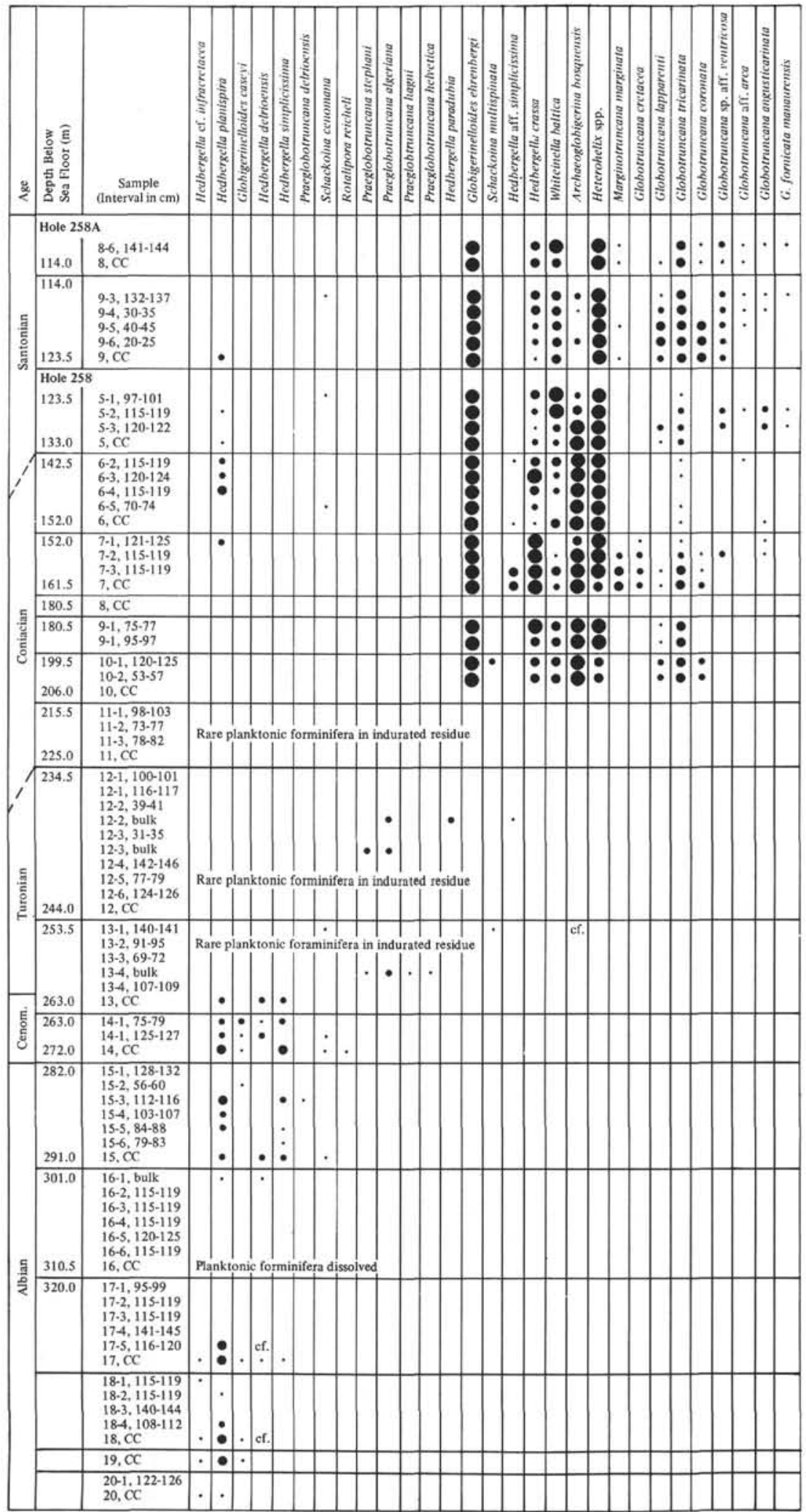

Abundance: abundant -common •few •rare.

Figure 3. Distribution of Cretaceous planktonic foraminifera at Site 258. 
manian, except for the one fragment mentioned above, and a few species of Hedbergella again dominate these assemblages.

\section{Turonian}

Turonian planktonic foraminifera could be identified in three samples: in Core 12, Sections 2 and 3, and in Core 13, Sections 3 and 4. Unfortunately, both were "bulk samples" of semiliquified chalk, and their exact stratigraphic position is therefore not certain. In both cores (except for Sample 258-13, CC) only inadequate planktonic assemblages could be isolated from the solid core material, however, and these samples may therefore at least furnish a minimum age for this interval. Since the assemblage in Sample 13, CC is definitely of Cenomanian age, it is highly probable that these bulk samples are nevertheless more or less reliable with respect to their stratigraphic position.

The preservation of the few specimens which were found in these samples is less favorable than in the underlying unit, and the identification must in some cases remain uncertain. The assemblages consist of keeled Praeglobotruncana and large Hedbergella, the smaller Hedbergella being most probably eliminated by diagenetic dissolution.

The assemblages are characterized by the predominance of representatives of Praeglobotruncana. $P$. algeriana is the most common form and is accompanied by $P$. hagni, possible $P$. stephani and, in Core 12 , Section 2 , by $P$. cf. imbricata and Hedbergella? paradubia. One fragment of Praeglobotruncana helvetica was found in Core 13, Section 3-4. These assemblages have to be placed in the middle to upper Turonian. Lower Turonian could not be recognized. A stratigraphic break seems probable during that time but, due to the incomplete microfossil record, this cannot be determined precisely.

\section{Coniacian-Santonian}

Abundant planktonic foraminifera of Coniacian and Santonian age occur in the uppermost part of the Cretaceous sequence at Site 258, between Core 10 and the Cretaceous/Tertiary unconformity. The most striking feature of these assemblages is the proliferation of mostly small globigerine-shaped and heterohelicid taxa. Double-keeled globotruncanid species are quantitatively minor constituents in most of the samples, particularly in the Coniacian. Benthonic foraminifera are usually rare, and the assemblages are typical for a pelagic environment. Fragments of Inoceramus occur frequently, mainly in the Santonian.

The identifications of nonkeeled taxa in this report have to be considered preliminary. Some of the species are taken in a very broad sense, and further examination may eventually show the presence of more than one species in some cases.

The most abundant species in all samples is Globigerinelloides ehrenbergi. In the majority of samples it is followed by representatives of the genus Heterohelix. Among the globigerine-shaped forms, three main species or groups can be distinguished: Archaeoglobigerina bosquensis, Whiteinella baltica, and Hedber- gella crassa. Hedbergella aff. simplicissima, H. planispira, Schackoina cenomana, and $S$. multispinata occur in some of the samples.

Among the double-keeled globotruncanid forms Globotruncana tricarinata is the most frequent; it occurs in almost all of the samples. The assemblages in Cores 258-9 and 258-10 are more restricted than those higher in the section, and contain only G. tricarinata, G. lapparenti, and $G$. coronata. Between Core 7 and the top of the preserved Cretaceous, we find discontinuous occurrences of Marginotruncana marginata, Globotruncana angusticarinata, $G$. aff. ventricosa, $G$. arca, and $G$. fornicata manaurensis, the last two being restricted to the upper part of the section.

The Coniacian/Santonian boundary is difficult to locate precisely with the available material, since such important stratigraphic markers, as Globotruncana concavata and the $G$. fornicata group, are either missing or very rare. $G$. fornicata manaurensis has not been found below Core 5 , and the Coniacian/Santonian boundary is therefore tentatively placed between Cores 5 and 6 (cf. Barr, 1972). However, since this species is isolated in its occurrence, we might well have missed its first appearance in our small samples, and this boundary may in fact be situated slightly below this level (see Bukry, this volume, Chapter 29).

Globotruncana sp. aff. ventricosa is another interesting form from this interval. It seems to have evolved from $G$. coronata by becoming more convex on the umbilical side. Strongly convex forms are close to what has been described by Pessagno (1967) as $G$. rosetta from the Campanian of Texas. However, the rest of the assemblage is definitely not younger than Santonian (cf. $G$. coronata, $G$. angusticarinata).

\section{COMPARISONS}

\section{Albian Assemblages at Sites 256, 257, and 258}

Albian assemblages of these three sites are remarkably different from each other with respect to their preservation and their specific composition.

At Site 256 the preservation is rather poor and the diversity very low. This is probably due to selective solution during deposition and diagenetic recrystallization.

Preservation and diversity are more favorable at Sites 257 and 258. The slight age difference may in part account for the different specific compositions, but here also, selective solution may be the principal reason why some species, such as the small Hedbergella aff. sigali and Ticinella sp. A, were found only in a particular interval of Site 257.

Hedbergella planispira is the most common species at all three sites. The total absence of the genus Rotalipora and the sporadic occurrence of Ticinella only at Site 257 are significant features of all assemblages and are most probably due to the paleoclimatic situation of this area during the Cretaceous, as will be discussed below.

\section{Upper Cretaceous of Western Australia}

Upper Cretaceous planktonic foraminifera were described from the Carnavron Basin (Edgell, 1957; 
Belford and Scheibnerova, 1971) and from the Perth Basin (Belford, 1960). The writer had the opportunity to collect samples at the type locality of the Gingin Chalk (Santonian) north of Perth, in order to compare them with the Santonian assemblages from Site 258.

Although these samples contain good assemblages of double-keeled Globotruncana, mainly G. tricarinata and $G$. marginata, the same predominance of nonkeeled species (Globigerinelloides, Hedbergella, Whiteinella, and Heterohelix) was again observed. Although some differences in the specific composition must be noted, the planktonic assemblages from the Gingin Chalk can well be compared with those from Site 258 , and reflect an extratropical, transitional paleoenvironment. The Gingin Chalk, however, shows richer assemblages of benthonic foraminifera and more abundant fragments of Inoceramus. Deposition of this sediment was therefore in slightly shallower water than at Site 258 .

Similar relations between keeled and nonkeeled planktonic foraminifera were also reported by Edgell (1957) from the Campanian and Maestrichtian of the Carnavron Basin, where the abundance of Rugoglobigerina is usually five times greater than that of Globotruncana.

\section{PALEOECOLOGY}

The following observations made on the Cretaceous planktonic assemblages of Leg 26 are significant for paleoecologic and paleoclimatic interpretations:

1) The low diversity of the assemblages. As already noted, the rare occurrence of Ticinella and the total absence of the Rotalipora ticinensis group are striking features of the Albian assemblages, and also in the Cenomanian of Site 258 Rotalipora is very rare. In the Coniacian to Santonian part of the section at this site some important biostratigraphic markers of worldwide distribution, such as Globotruncana fornicata or G. concavata are rare or totally absent.

2) The strong predominance of nonkeeled and mostly small species of the genera Hedbergella, Globigerinelloides, Whiteinella, Archaeoglobigerina, and Heterohelix over keeled globotruncanid species in the Coniacian to Santonian of Site 258. Representatives of the genera Globotruncana and Marginotruncana contribute usually less than $5 \%$ of the total planktonic foraminifera.

Such assemblages can generally be interpreted to be the expression of either a restricted environment (shallow water, closed basin) or of relatively cool-water temperature (Bandy, 1967). Cretaceous planktonic microfaunas, which in many ways can be compared with our assemblages from the eastern Indian Ocean, were described by Douglas and Rankin (1969) from Bornholm. There, according to these authors, the restricted diversity reflects the lower water temperature of the Boreal province as well as the paleogeographic situation in this North European inland seaway. Tethyan species, such as Globotruncana concavata and G. fornicata, were not found in the Santonian of Bornholm, and also the predominance of nonkeeled globigerine-shaped and heterohelicoid species over keeled globotruncanid forms stresses the similarity of the
Bornholm and the eastern Indian Ocean assemblages. In contrast to this, keeled species strongly dominate the Santonian assemblages of the Central to Northwestern Pacific collected during Leg 6 (Douglas, 1971). In this area $G$. fornicata is the most frequent species, followed by $G$. concavata.

The data obtained during Legs 22, 26, and 27 of the Deep Sea Drilling project clearly demonstrate that during the Albian and the Upper Cretaceous, open, marine conditions with water depths near or below the lysocline prevailed, and there are no indications that the Naturaliste Plateau would have been part of a more or less closed basin during the Upper Cretaceous. The assemblages from Sites $256-258$, and most probably also from Site 255 , therefore indicate a relatively cool paleoenvironment with open-marine conditions during the Cretaceous. A more detailed evaluation of the Naturaliste Plateau sequence demonstrates that the proportion of keeled globotruncanid forms among the total planktonic foraminifera was highest (but still less than $20 \%$ ) in the Santonian. We can therefore assume a slight warming trend since the Albian.

\section{SYSTEMATICS}

Genus GLOBIGERINELLOIDES Cushman and ten Dam, 1948 Globigerinelloides caseyi (Bolli, Loeblich and Tappan) (Plate 2, Figure 9)

Planomalina caseyi Bolli, Loeblich, and Tappan, 1957, U.S. Nat1. Mus. Bull. 215 , p. 24, pl. 1 , fig. 4,5 .

Following Eicher and Worstell (1970) and Barr (1972) the small planispiral forms belonging to the genus Globigerinelloides, which occur in the Albian of Site 257 and in the Albian and Cenomanian of Site 258 , were named $G$. caseyi. There is a considerable amount of variation in the form and arrangement of the last chambers, but due to the generally rare occurrence, it cannot be decided whether eventually more than one species is present.

\section{Globigerinelloides ehrenbergi ( Barr) \\ (Figure 4; Plate 4, Figures 1-5)}

Planomalina ehrenbergi Barr, 1962, Paleontology, v. 4, pt. 4, p. 563, pl. 69 , fig. 1a, b.

In most of the samples from the Coniacian and Santonian of Site 258 a small Globigerinelloides is the most abundant species in the planktonic foraminiferal assemblages. Large specimens may reach maximum diameters of $0.3 \mathrm{~mm}$, but most of them are considerably smaller. The test is rather evolute and shows 7-8 chambers in the last whorl. Earlier chambers of the last whorl are slightly rugose (Figure 4). The form can well be compared with Barr's species originally described from the Coniacian of the Isle of Wight (England).

Genus SCHACKOINA Thalmann, 1932

Schackoina cenomana (Schacko) (Plate 1, Figure 6)

Siderolina cenomana Schacko, 1897, Archiv Ver. Fr. Naturg. Mecklenburg, v. 50 (1896), p. 166, pl. 4, fig. 3-5.

This species has been found as a minor constituent of the Cenomanian assemblages at Site 258. Isolated specimens were also found in the upper Albian of Sites 256 (Plate 1, Figure 6) and 258. Although very small, they cannot be distinguished from the typical Schackoina cenomana, and we may therefore assume that this species extends slightly below the Albian/Cenomanian boundary. 


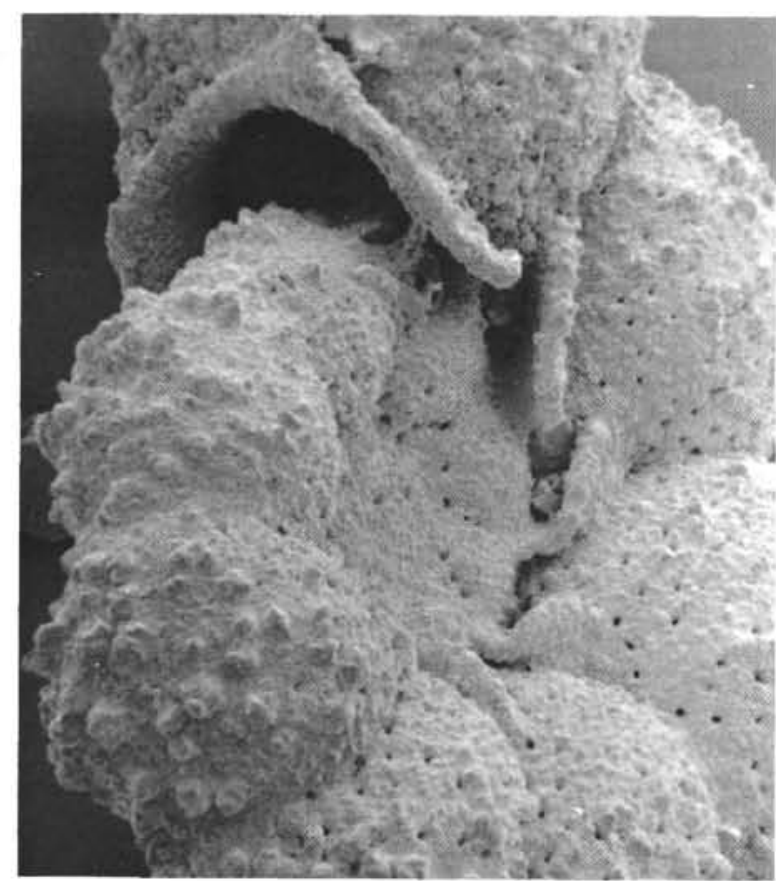

Figure 4. Oblique view of the umbilical area of Globigerinelloides ehrenbergi Barr, showing relict apertures. Same specimen as in Plate 4, Figure 3. Magnification $\times 500$.

\section{Schackoina aff. cenomana (Schacko)}

(Plate 5, Figures 14-16)

A Schackoina, which is very closely related to $S$. cenomana, occurs in some of the samples from the Santonian of Site 258. It differs from the type in being larger (up to $0.5 \mathrm{~mm}$ maximum diameter without spines) and in having more elongated chambers. Scattered occurrences of $S$. cenomana in the Coniacian and lower Santonian were also reported from California (Douglas, 1969).

$S$. multispinata (Cushman and Wickenden) which is often quoted from Senonian sediments, could only be identified in one sample from Site 258.

Genus HEDBERGELLA Brönnimann and Brown, 1968

\section{Hedbergella crassa (Bolli)}

(Plate 4, Figures 12, 13)

Praeglobotruncana crassa Bolli, 1959, Am. Paleontol. Bull., v. 39, no. 179 , p. 265 , pl. 21 , fig. $1,2$.

This species is abundant or common in most samples from the Coniacian and Santonian of Site 258. In contrast to Hedbergella(?) sp. A and Archaeoglobigerina bosquensis, it has a smooth test surface. An apertural lip can be seen in most specimens, but is always very narrow.

\section{Hedbergella delrioensis (Carsey)}

(Plate 3, Figures 15-18)

Globigerina cretacea d'Orbigny var. delrioensis Carsey, 1926, Texas Univ. Bull. 2612, p. 43.

This species occurs as remarkably well-preserved specimens in the upper Albian and Cenomanian of Site 258. As already noted by Eicher and Worstell (1970), the species grades into $H$. simplicissima $(=H$. amabilis). Both show the same type of spinose surface structure and obviously belong to the same stock, which most probably has its origin in the older $H$. infracretacea.

\section{Hedbergella cf. infracretacea and Hedbergella aff. infracretacea (Glaessner) \\ (Plate 2, Figures 1-4)}

Typical assemblages of this species do not occur at the Leg 26 sites. A few specimens at the base of the Site 258 section can most probably be related to it. The forms called $H$. aff. infracretacea at Site 257 differ from the type in having $5 \frac{1}{2}$ to 6 instead of 5 chambers in the last whorl. They were kindly examined by Dr. M. F. Glaessner.

Hedbergella planispira (Tappan)

(Plate 1, Figures 1-5; Plate 2, Figures 5-8;

Plate 3, Figures 1-8; Plate 4; Figures 10, 11)

Globigerina planispira Tappan, 1940, J. Paleontol. v. 14, no. 2, p. 122, pl. 19, fig. 12.

This species is the most abundant of planktonic foraminifera in the majority of the Albian samples from Sites 256-258. A certain amount of variation can be observed regarding the intensity of trochospiral coiling and the diameter of the umbilicus, some forms being almost planispirally coiled and showing an open umbilicus, others being more trochospirally coiled, but still with a flat spiral side, and having a narrow umbilicus. In general, there is, however, a good agreement with the specimens figured by Loeblich and Tappan (1961).

H. planispira occurs also in the Coniacian and Santonian of Site 258 (Plate 4). In this interval, however, it is no longer the dominant form as in the Albian.

\section{Hedbergella aff. sigali Moullade}

(Plate 1, Figures 7-16)

Description: Very small globigeriniform planktonic foraminifera with a diameter of $0.1-0.15 \mathrm{~mm}$. About 9 chambers increasing rapidly in size and arranged in a low trochospiral coil of 2 to $2 \frac{1}{4}$ whorls with 4 chambers in the final whorl. The last chamber is variable in size and form and may be greater or smaller than the preceding one. The outline of the test can therefore vary from subovate to subquadrangular, but is always lobate. The sutures are distinct, depressed, radial to slightly curved on the spiral side, and radial on the umbilical side. The surface of the test is smooth and finely perforate, the aperture interiomarginal umbilical-extraumbilical with a bordering lip, the umbilicus usually narrow.

Remarks: The form and arrangement of the chambers and the aperture of our specimens seem to be identical with $H$. sigali from the Barremian and lower Aptian of southeastern France, except that the type of $H$. sigali is almost twice as large as the present form from Site 257. A biostratigraphical problem is also raised, since $H$. sigali has so far not been reported from the upper Aptian and lower Albian. However, this very small form can easily be overlooked, and the presently known stratigraphic record may therefore be incomplete.

\section{Hedbergella simplicissima (Magné and Sigal) \\ (Plate 3, Figures 9-13, Plate 4, Figures 6-9)}

Hastigerinella simplicissima Magné and Sigal, 1954, Géol. Soc. France Bull., sér. 6, v. 3 (1953), p. 487, pl. XIV, fig. Ila-c.

Hedbergella amabilis Loeblich and Tappan, 1961, Micropaleontology, v. 7 , no. 3 , p. 274 , pl. 3 , fig. $1-10$.

In most modern papers on Albian and Cenomanian planktonic foraminifera, this species is usually listed as Hedbergella amabilis. According to Caron (1966), however, Loeblich and Tappan's species from the Cenomanian of the United States is most probably a junior synonym of Hastigerinella simplicissima described from the lower Cenomanian of Tunisia. Although the original illustrations of Hedbergella amabilis may better show the main features and the variability of the species, a comparison of the original descriptions and illustrations leaves little doubt about the synonymy of the two names.

In the Albian and Cenomanian of Site 258 a gradual transition from Hedbergella delrioensis to $H$. simplicissima can be observed. Both species show the same kind of hispid test surface.

H. simplicissima occurs also in the Coniacian of Site 258, (Plate 4, Figures 6-9), but the tests have a greater diameter and are more compressed, the tendency to develop radially elongated chambers being usually more pronounced than in the Albian and Cenomanian. 
In fact, Caron (1966), for this reason, placed the species into Clavihedbergella. This could certainly be justified for these stratigraphically high occurrences at Site 258, but considering the observed transition to Hedbergella delrioensis in the Albian and Cenomanian we prefer to leave it in the genus Hedbergella.

Porthault (in Donze et al., 1970) recorded this form in the Coniacian and Santonian of southeastern France and has given a new name to it (Hedbergella flandrini). However, since Caron has found it continuously from the Cenomanian to the Santonian, it seems that we are dealing with one and the same species ranging from the upper Albian to the Santonian and showing a slow gradational evolution towards larger and more compressed tests. A separation into two different species does not seem justified at present.

\section{Genus PRAEGLOBOTRUNCANA Bermúdez \\ Praeglobotruncana algeriana Caron (Plate 4, Figures 1-3)}

Globotruncana (Globotruncana) aff. renzi Thalmann-Gandolfi, Reichel, 1950, Ecolog. Geol. Helv., v. 42/2, pl. XVI, fig. 8; pl. XVII, fig. $8 \mathrm{a}, \mathrm{b}$.

Praeglobotruncana algeriana Caron, 1966, Rev. Micropaléontol., v. 9, no. 2, p. 74

Although the preservation of the Turonian microfossils at Site 258 is only moderate, the presence of two keels is clearly visible on most specimens, which belong to the genus Praeglobotruncana.

Eicher and Worstell (1970) have placed $P$. algeriana in synonymy with Globotruncana intermedia difformis Gandolfi, and called it Praeglobotruncana difformis. Comparison of the original descriptions and the type figures demonstrates, however, that we are dealing with two different species, occurring in different stratigraphic intervals.

In the Turonian of Site 258, P. algeriana is accompanied by rare $P$. hagni Scheibnerova and a single fragment of $P$. helvetica (Bolli).

\section{Praeglobotruncana delrioensis (Plummer)}

(Figures 5, 6, Plate 3, Figure 14)

Globorotalia delrioensis Plummer, 1931, Texas Univ. Bull. 3101, p. 199 , pl. 13, fig. 2.

One single specimen of this species has been found in the upper Albian of Site 258, shortly below the Albian/Cenomanian boundary. Instead of a distinct keel there is a wide lateral band of a coarse hispid structure which is for the greater part, although not entirely, imperforate.

\section{Genus TICINELLA Reichel, 1950}

In some intervals of Site 257 two species of nonkeeled trochospiral planktonic foraminifera showing secondary apertures on the umbilical side of the test, could be found. With few exceptions the secondary apertures are umbilical in position and are not true supplementary apertures, but only umbilical relicts of the primary aperture which are not covered by the following chamber (Plate 1, Figure 18). This is the type of relict aperture typical for the genus Globigerinelloides (see Figure 4). In the genus Ticinella the umbilically situated supplementary apertures are placed on a plate-like umbilical extension (see, e.g., Caron, 1971) and are therefore true supplementary openings. On the last chambers the supplementary apertures are located in an extraumbilical position on the sutures. In our material from Site 257, true supplementary apertures could only be found on one specimen of Ticinella aff. raynaudi raynaudi (Plate 1, Figure 17), but never in the case of Ticinella sp. A. It should be pointed out, however, that due to the fragile nature of the Site 257 specimens, in all cases so far found, at least the last chamber was broken and therefore more specimens may originally have shown these sutural secondary apertures on the last chambers. For this reason also the second of these two species, which only shows the Globigerinelloides type of aperture, is tentatively placed in the genus Ticinella, although based on the material available so far, it does not quite correspond to the definition of this genus.

It can be assumed that the type of supplementary aperture observed in the Site 257 material, represents an early stage in the development of the genus Ticinella. This is also supported by the stratigraphic position of the samples, which, according to the nannoplankton, is middle Albian (Prediscosphera cretacea Zone).

\section{Ticinella aff. raynaudi raynaudi Sigal}

(Plate 2, Figures 17-19)

In Core 7 at Site 257 a few specimens of a rather typical Ticinella were found, on which in one case a true supplementary sutural aperture in an extraumbilical position could be found. The test is distinctly trochospiral, usually with a flat spiral side, and has 6-7 chambers in the last whorl. These specimens can well be compared with Ticinella raynaudi raynaudi, except for the differences in the supplementary apertures. Transitions to $T$. roberti (Gandolfi) can be observed (Plate 2, Figure 16). The tests of our specimens are all incomplete and lack the last chambers.

\section{Ticinella sp. A}

(Plate 2, Figures 10-15)

In the middle/upper Albian of Site 257 a rather evolute, relatively flat, nonkeeled species occurs, which in its general aspect has many affinities to Praeglobotruncana, but definitely differs from this genus in lacking any indication of the development of a keel. The primary aperture is interiomarginal umbilical-extraumbilical. In some specimens very small relict apertures can be observed. Their position is intraumbilical, and they can not be considered true secondary openings, as discussed above. No specimens have been found so far where these secondary openings become extraumbilical on the last chambers.

The test is smooth, finely perforate, and, in the material from Site 257 , rather fragile. Complete tests are therefore rare, the last chamber being broken in most cases. Although we are probably dealing with a new species, no new name is given so far, since the available material from Site 257 is insufficient. Like Hedbergella minuta, with which it has been found, this species occurs only in the Albian of Site 257.

\section{Genus WHITEINELLA Pessagno, 1967}

Whiteinella baltica Douglas and Rankin

(Plate 5, Figures 7-13)

Whiteinella baltica Douglas and Rankin, 1969, Lethaia, v. 2, p. 197, fig. 9A-I.

This species, originally described from the Coniacian and Santonian of Bornholm, is similar to Archaeoglobigerina bosquensis in its somewhat rugose test surface, but differs from this species in being smaller and in showing a lower trochospiral coil and more rapidly increasing chambers, the outline of the test becoming therefore more elongate instead of circular. Apertural flaps can be observed (Plate 5, Figure 10), but the portici, if they were present, were broken. The inclusion in the genus Whiteinella can therefore not be proved on the basis of the present material. $W$. baltica is common to abundant in most samples from the Coniacian and Santonian of Site 258. Its presence is biogeographically interesting, since it has so far been described only from boreal regions of northern Europe.

\section{Genus ARCHAEOGLOBIGERINA Pessagno 1967 \\ Archaeoglobigerina bosquensis Pessagno}

(Plate 5, Figures 1-6)

Archaeoglobigerina bosquensis Pessagno, 1967, Paleont. Am., v. V, no. 37 , p. 316 , pl. 60 , fig. $7-12$.

In the original description this species is defined to have a relatively high trochospiral coil and to show 6-7 chambers in the last whorl, but the figured holotype and paratype have only 5 or 6 chambers in the last whorl. Our specimens show $4 \frac{1}{2}$ to 5 chambers in the last whorl and usually have a higher trochospiral coiling than the types. On the other hand they correspond well with what Douglas and Rankin (1969) described from Bornholm under this name. A. bosquensis is the most abundant and also the largest of the globigerine-shaped forms in the Coniacian and Santonian of Site 258.

\section{Genus GLOBOTRUNCANA Cushman, 1927}

A number of double-keeled species occur in the Coniacian and Santonian of Site 258 . Due to their greater size they are immediately noticeable among the mostly small nonkeeled planktonic foraminifera in the assemblages, but in fact numerically they form only a very minor proportion of these assemblages. Most species are well known in the literature and are therefore only figured in this paper (Plates 6 and 7). One form however, will be briefly discussed here. 


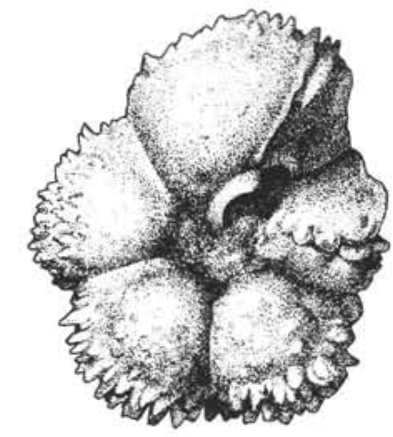

0

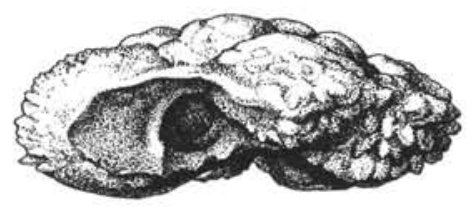

$0.5 \mathrm{~mm}$

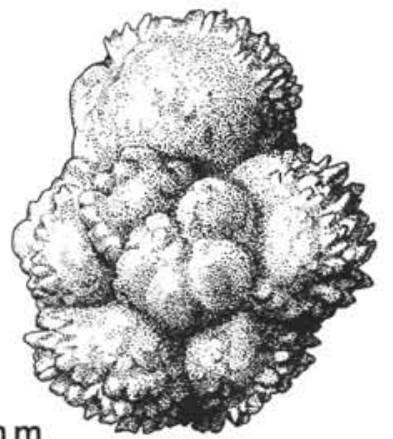

Figure 5. Praeglobotruncana delrioensis (Plummer). Sample Site 258-15-3, 112-116 cm. Same specimen as in Plate 3, Figure 14. Magnification $\times 120$.

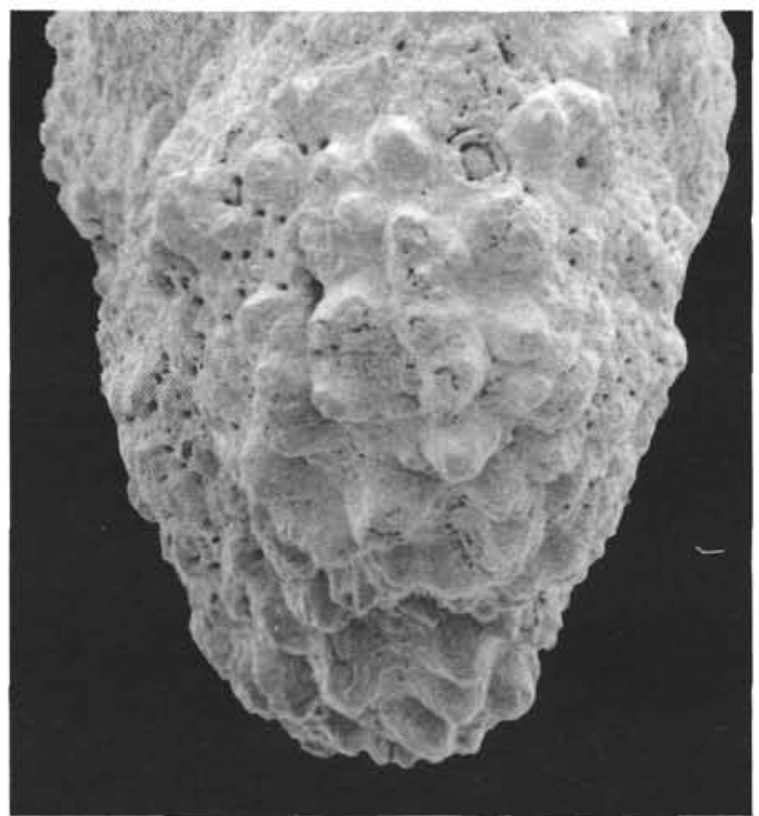

Figure 6. Praeglobotruncana delrioensis (Plummer). Detail of specimens in Figure 5 and Plate 3, Figure 14 , showing a pustulose lateral band instead of a true keel. Magnification $\times 500$.

Globotruncana sp. aff. ventricosa White (Plate 7, Figures 1-10)

This large form with a diameter up to $0.8 \mathrm{~mm}$ occurs in most of the Santonian samples from Site 258, but also has an isolated occurrence in Core 7, which is placed in the Coniacian. Large specimens show up to $3 \frac{1}{2}$ whorls with slowly increasing chambers. In the last half whorl the size of the chambers often remains constant. The spiral side is slightly convex, flat, or, in some cases, even slightly concave. The umbilical side is more or less, in large specimens often strongly, convex. The two keels are distinct and not very closely spaced. A number of specimens show irregular growth with one or few either smaller or distorted chambers.

Many specimens show transitional features to Globotruncana coronata and the form seems therefore to have evolved from this species by becoming more convex on the umbilical side. The most convex specimens are already close to $G$. ventricosa. A similar form has also been figured by Pessagno (1967, pl. 70, fig. 9-12) as $G$. rosetta. The latter species is a single-keeled form, however, close to G. elevata, and Pessagno's determination can therefore not be correct. At present it seems appropriate to interpret our specimens as being transitional between $G$. coronata and $G$. ventricosa.

\section{CALCISPHAERULIDAE incertae sedis Genus PITHONELLA Lorenz}

This group of small microfossils has a widespread occurrence at some sites in the eastern Indian Ocean, particularly in the Leg 27 sites, and is described and discussed in detail by Bolli (in press). In the material from Leg 26, Pithonella occurs mainly in the middle Albian of Site 257. These samples were examined by Bolli and will be discussed with the Leg 27 sites. Two of the species occurring in Site 257 are described and figured by Bolli: Pithonella francadecimae Bolli (pl. 1, fig. 17) and P. hiertzleri Bolli (pl. 1, fig. 18).

\section{ACKNOWLEDGMENTS}

The writer wishes to express his thanks to the Deep Sea Drilling Project for the opportunity to participate in Leg 26, to Dr. M. Caron (Fribourg) and F. Allemann (Berne) for many helpful suggestions regarding taxonomy and biostratigraphy of Cretaceous planktonic foraminifera, to Dr. A. Cockbain (Perth) for leading a field trip to the Gingin area, and to $\mathrm{Mr}$. G. Papaux (Fribourg) fro the drawing of Figure 5. Scanning electron micrographs were taken by Mr. F. Zweili at the Geological Institute of the University of Berne.

\section{REFERENCES}

Bandy, O. L., 1967. Cretaceous planktonic foraminiferal zonation: Micropaleontology, v. 13, p. 1-31.

Banner, F. T. and Blow, W. H., 1960. Some primary types of species belonging to the superfamily Globigerinacea: Cushman Found. Foram. Res. Contrib., v. 11, p. 1-41.

Barr, F. T., 1962. Upper Cretaceous planktonic foraminifera from the Isle of Wight, England: Palaeontology, v. 4, p. $552-580$.

1972. Cretaceous biostratigraphy and planktonic foraminifera from Libya: Micropaleontology, v. 18, p. 146.

Belford, D. J., 1960. Upper Cretaceous foraminifera from the Toolonga Calcilutite and Gingin Chalk, Western Australia: Australia Bur. Min. Res., Geol. Geophys. Bull. 57, p. I-198.

Belford, D. J. and Scheibnerova, V., 1971. Turonian foraminifera from the Carnavron Basin, Western Australia, and their paleogeographic significance: Micropaleontology, v. 17, p. 331-344.

Bolli, H. M., in press. Jurassic and Cretaceous Calcisphaerulidae from DS̊DP Leg 27, Eastern Indian Ocean. In Heirtzler, J. R., Veevers, J. J. et al., Initial Reports of the Deep Sea Drilling Project, Volume 27: Washington (U.S. Government Printing Office). 
1959. Planktonic foraminifera from the Cretaceous of Trinidad, B.W.I.: Am. Paleontol. Bull., v. 39, no. 179, p. 257-277.

Burckle, L. H., Saito, T., and Ewing, M., 1967. A Cretaceous (Turonian) core from the Naturaliste Plateau, southeast Indian Ocean: Deep-Sea Res., v. 14, p. 421-426.

Caron, M., 1966. Globotruncanidae du Crétacé supérieur du synclinal de la Gruyère (Préalpes Médianes, Suisse): Rev. Micropaleontol., v. 9, p. 68-93.

1971. Quelques cas d'instabilité des caractères génériques chez les foraminiferes planctoniques de l'Albien: Plank. Conf. 2nd Roma 1970 Proc., Farinacci, A. (Ed.), Roma (Tecnoscienza).

Donze, P. Porthault, B., Thomel, G., and de Villoutreys, O., 1970. Le Sénonien inférieur de Puget-Théniers (AlpesMaritimes) et sa microfaune: Geobios, no. 3, v. 2, p. 41103.

Douglas, R. G., 1971. Cretaceous foraminifera from the northwestern Pacific Ocean: Leg 6, Deep Sea Drilling Project. In Fischer, A. G., and Heezen, B. C., Initial Reports of the Deep Sea Drilling Project, Volume 6: Washington (U.S. Government Printing Office), p. 1027-1053.

Douglas, R. G. and Rankin, C., 1969. Cretaceous planktonic foraminifera from Bornholm and their zoogeographic significance: Lethaia, v. 2, p. 185-217.

Edgell, H. S., 1957. The genus Globotruncana in northwest Australia: Micropaleontology, v. 3, p. 101-126.

Eicher, D. L. and Worstell, P., 1970. Cenomanian and Turonian foraminifera from the Great Plains, United States: Micropaleontology, v. 16, p. 269-324.

Loeblich, A. R., Jr., and Tappan, H. 1961. Cretaceous planktonic foraminifera. Part 1-Cenomanian: Micropaleontology, v. 7, p. 257-304.

Pessagno, E. A., Jr., 1967. Upper Cretaceous planktonic foraminifera from the western Gulf Coastal Plain: Paleont. Am., v. 5, p. 245-445.

\section{ADDITIONAL SELECTED REFERENCES}

Douglas, R. G., 1969. Upper Cretaceous planktonic foraminifera in northern California, Part-Systematics: Micropaleontology, v. 15, p. 151-209.

Gandolfi, R., 1955. The genus Globotruncana in northeastern Colombia: Am. Paleontol. Bull., v. 36, p. 1-118.

Kent, H. C., 1969. Distribution of keeled Globotruncanidae in Coniacian and Santonian strata of the western interior region of North America: Internatl. Conf. Plankt. Microfoss. 1st Proc., v. 2, Leiden (Brill), p. 323-327.

Montanaro Gallitelli, E. 1955. Schackoina from the upper Cretaceous of the northern Apennines, Italy: Micropaleontology, v. 1, p. 141-146.

Moullade, M., 1966. Etude stratigraphique et micropaléontologique du Crétacé inférieure de la "Fosse vocontienne": Doc. Lab. Géol. Fac. Sci. Lyon, no. 15.

Porthault, B., 1969. Foraminiferes planctoniques et biostratigraphie du Cénomanien dans le sud-est de la France: Internatl. Conf. Plankt. Microfoss., 1st Proc., v. 2, Leiden (Brill), p. 526-546.

Reichel, M., 1950. Observations sur les Globotruncana du gisement de la Breggia (Tessin). Ecolog. Geol. Helv., v. 42, p. 596-617.

Risch, H., 1971. Stratigraphie der höheren Unterkreide der bayerischen Kalkalpen mit Hilfe von Mikrofossilien: Palaeontographica, v. 138A, p. 1-80.

Scheibnerova, V., 1971. The great Artesian Basin, Australia, a type area of the Austral biogeoprovince of the Southern hemisphere, equivalent to the Boreal biogeoprovince of the Northern hemisphere: Plankt. Conf. 2nd Roma 1970 Proc., Farinacci, A., (Ed.), Roma (Tecnoscienza), p. 1129-1138.

Sigal, J., 1966. Contribution à une monographie des Rosalines. 1. Le genre Ticinella Reichel, souche des Rotalipores: Ecolog. Geol. Helv., v. 59, p. 185-217. 


\section{PLATE 1}

Figures 1-16 magnification $\times 325$; Figures $17,18, \times 500$.

Figures 1-6 Upper Albian at Site 256. Sample 9-1, 120-122 c.

1-5. Hedbergella planispira (Tappan).

6. Schackoina cf. cenomana (Schacko).

Figures 7-18 Middle Albian from Site 257.

7-16. Hedbergella aff. sigali Moullade.

Sample 257-9-1, 105-109 cm.

17. Pithonella francadecimae Bolli.

Sample 257-7, CC.

18. Pithonella hiertzleri Bolli.

Sample 257-7, CC. 


\section{PLATE 1}

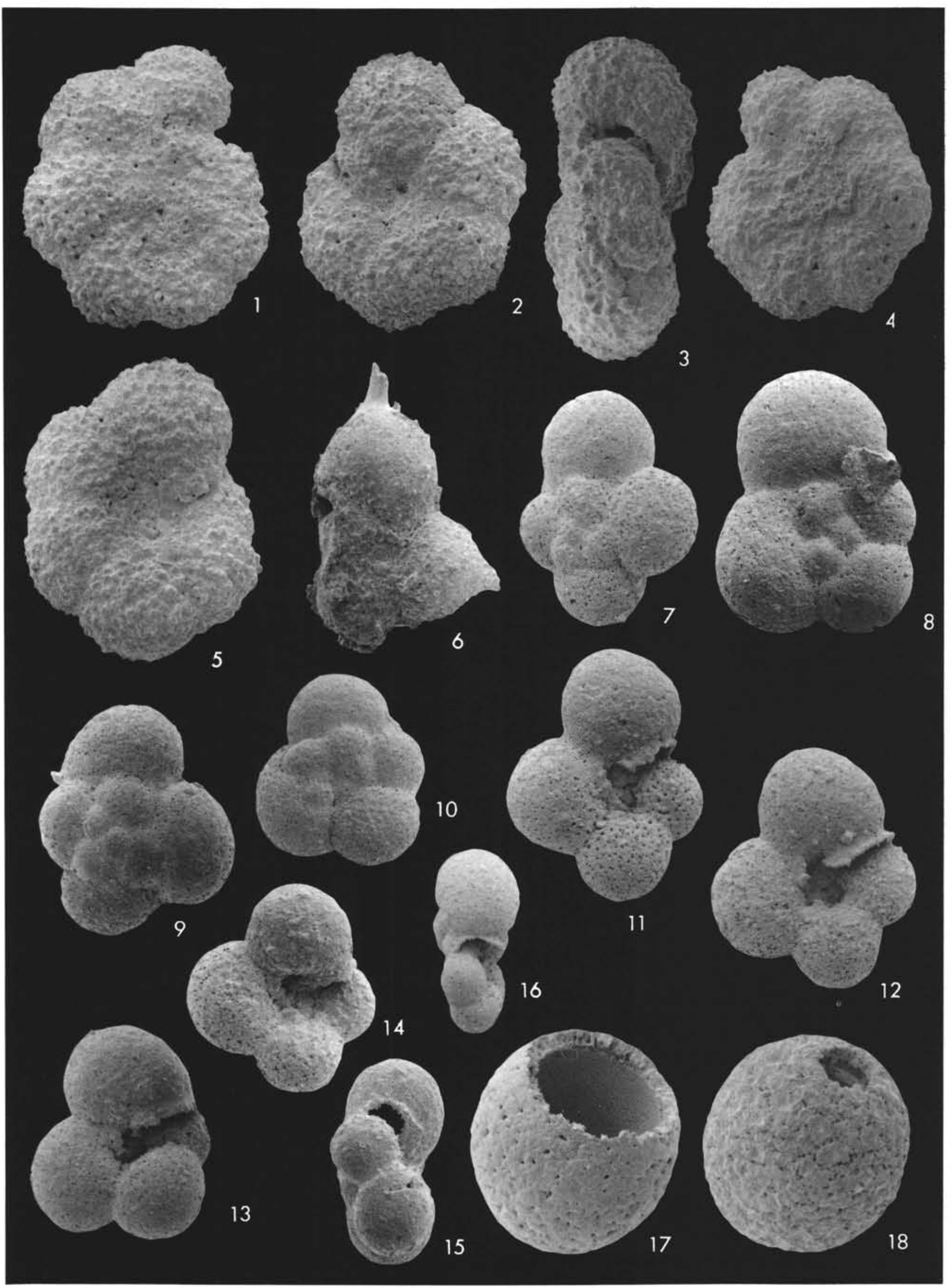




\section{PLATE 2}

Middle Albian planktonic foraminifera at Site 257. Magnification $\times 200$.

Figures 1-4 Hedbergella aff. infracretacea (Glaessner). Core 8, Section 1.

Figures 5-8 Hedbergella planispira (Tappan).

5. Sample 9-1, 105-109 cm.

6-8. Sample 7, CC.

Figure 9 Globigerinelloides caseyi (Bolli, Loeblich, and Tappan). Sample 7, CC.

Figures 10-15 Ticinella sp. A. Last chamber broken on all specimens.

$10,11,13,14$. Sample 9-1, 105-109 cm.

12, 15. Sample 7, CC.

Figure 16 Ticinella $\mathrm{cf}$. roberti (Gandolfi).

Sample 9-1, 105-109 cm.

Figures 17-19 Ticinella aff. raynaudi raynaudi Sigal.

17, 18. Sample 7, CC.

19: Sample 9-1, 105-109 cm. 
PLATE 2

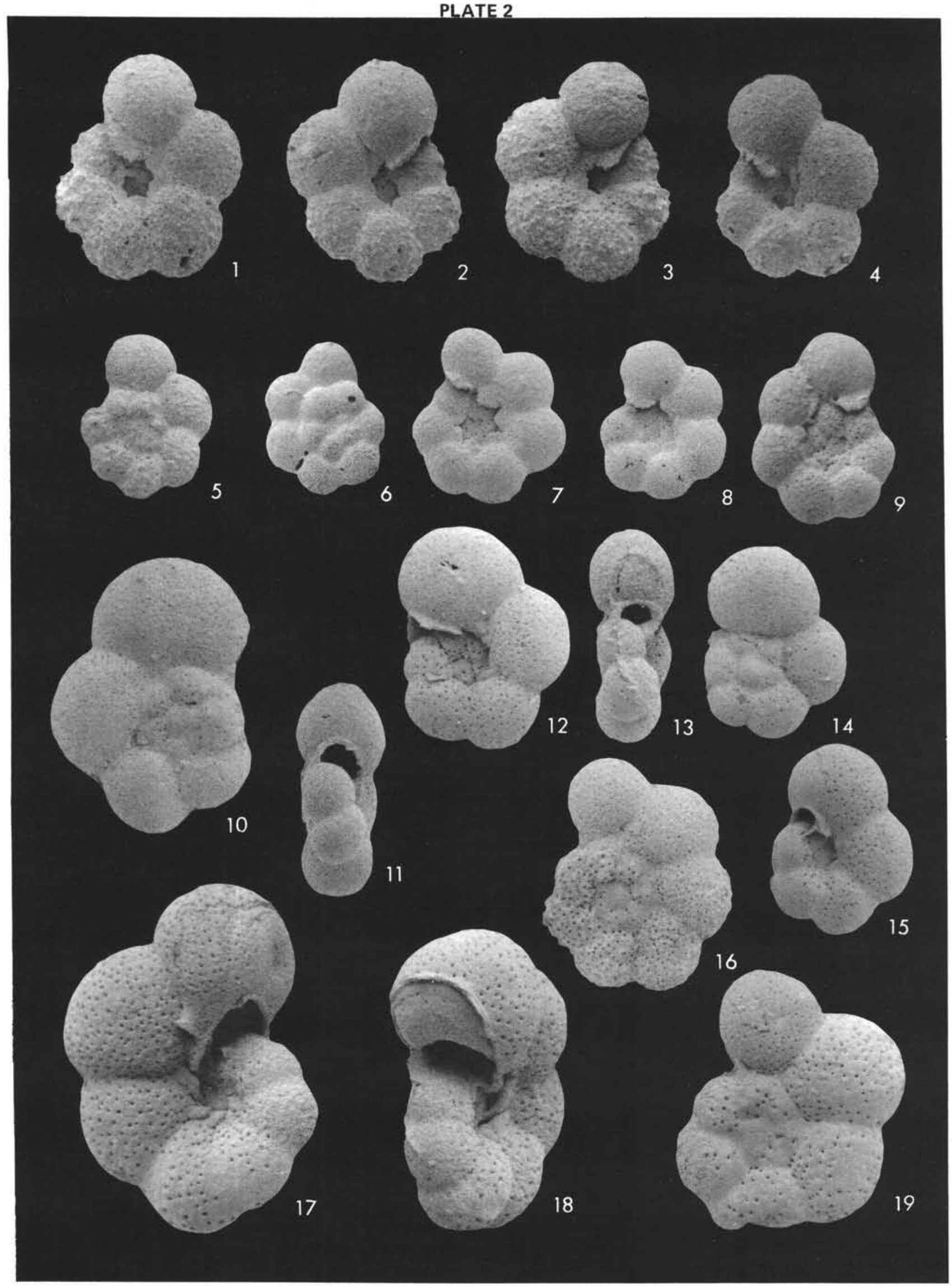




\section{PLATE 3}

Upper Albian planktonic foraminifera at Site 258

(Naturaliste Plateau). Magnification $\times 160$.

Figures 1-5 Hedbergella planispira (Tappan) Sample 17, CC.

Figures 6-8 Hedbergella planispira (Tappan), Sample 15, CC.

Figures 9-13 Hedbergella simplicissima Magné and Sigal, Sample 15, CC. (Figure 12 is transitional to Hedberbergella delrioensis [Carsey].)

Figure 14 Praeglobotruncana delrioensis (Plummer), Sample $15-3,112-116 \mathrm{~cm}$, see also Figures 5 and 6.

Figures 15-18 Hedbergella delrioensis (Carsey), Sample 15, CC. 
PLATE 3
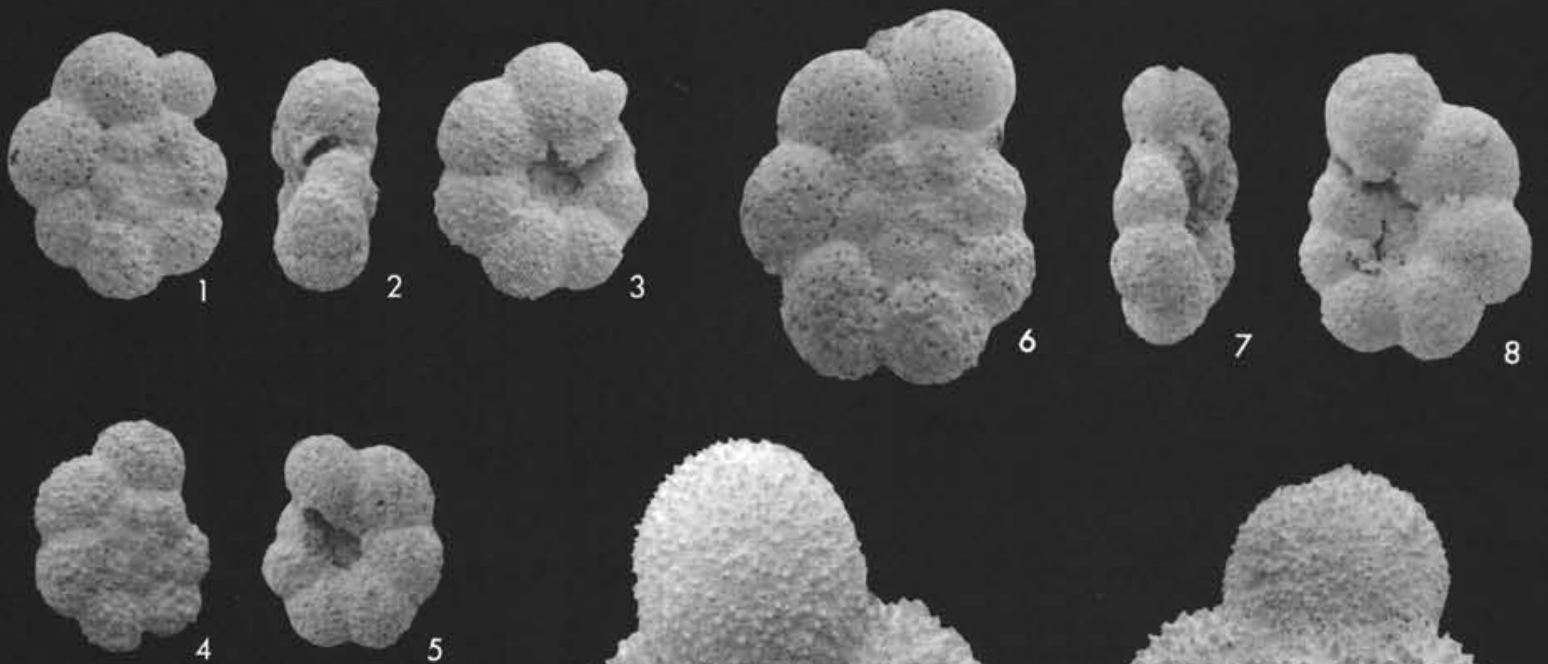

\section{5}
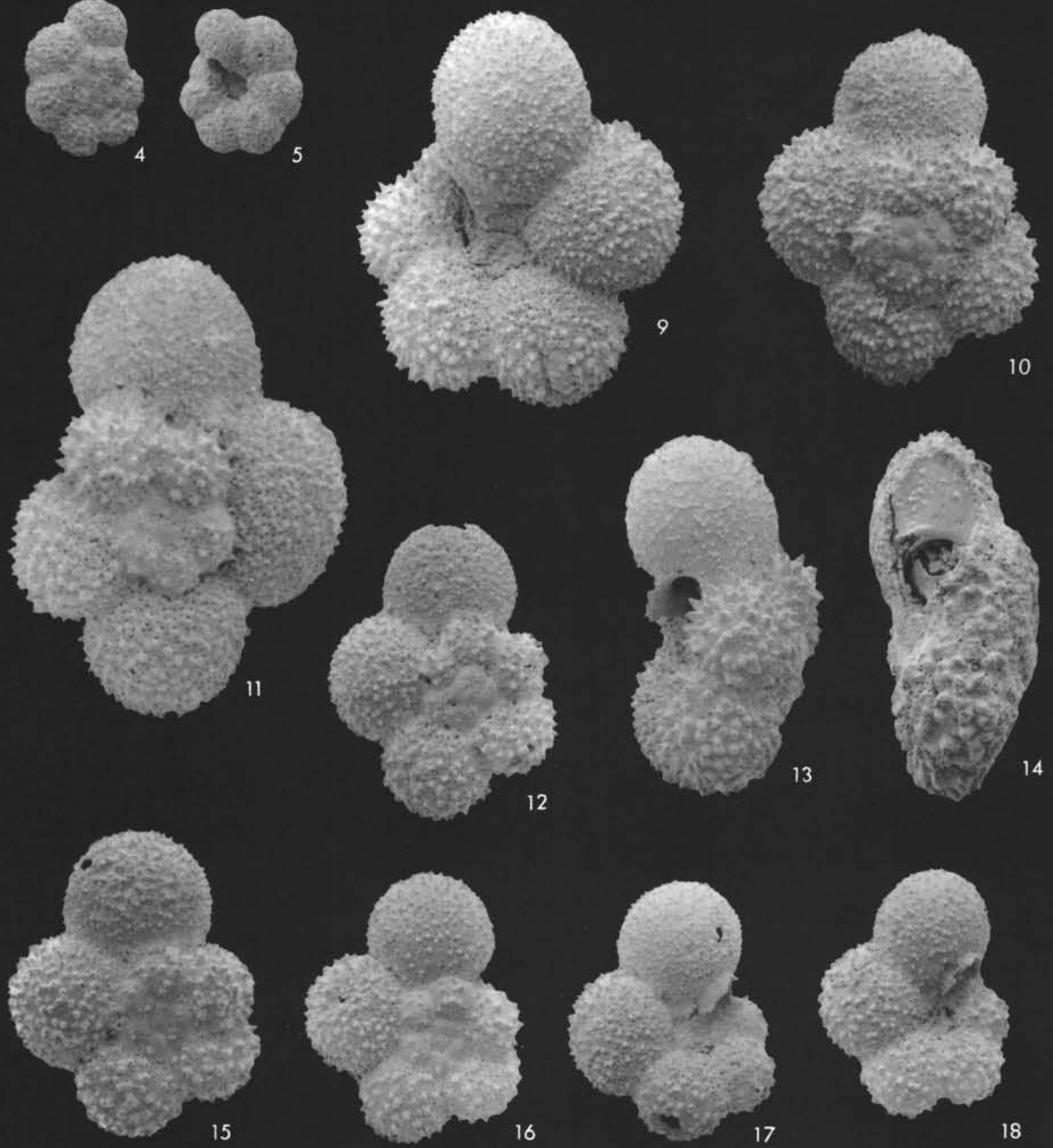

18 


\section{PLATE 4}

Coniacian and Santonian at Site 258 (Naturaliste Plateau).

Figures 1-5 Globigerinelloides ehrenbergi (Barr), Santonian. Magnification $\times 160$.

1, 5. Sample 258A-9-3, 132-134 cm.

2, 3. Sample 258A-8-6, 141-144 cm.

4. Sample 258A-8, CC.

Figures 6-9 Hedbergella aff. simplicissima Magné and Sigal, Coniacian. Magnification $\times 120$. Sample 258-7-3, $115-119 \mathrm{~cm}$.

Figures 10, 11 Hedbergella planispira (Tappan), Santonian. Magnification $\times 160$. Sample 258A-9-3, 132-134 $\mathrm{cm}$.

Figures 12,13 Hedbergella crassa (Bolli), Santonian.

12. Sample 258 A-9-3, $132-134 \mathrm{~cm}$. Magnification $\times 120$.

13. Sample 258A-9, CC. Magnification $\times 160$.

Figures 14, 15 Heterohelix reussi (Cushman), Coniacian. Sample 258-9-1, 95-97 cm.

14. Magnification $\times 100$.

15. Detail of Figure 14. Magnification $\times 750$. 


\section{PLATE 4}
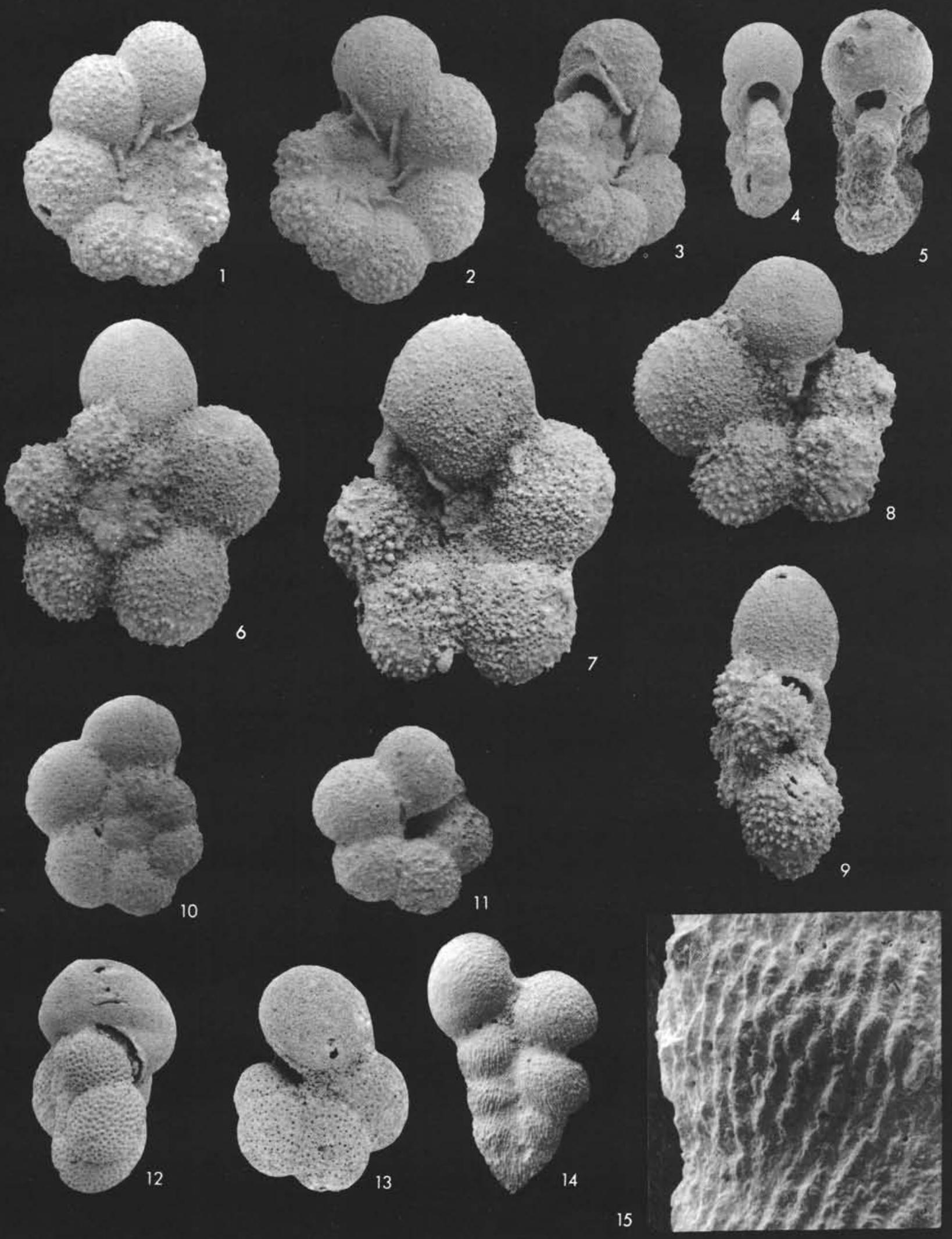
R. HERB

\section{PLATE 5}

Coniacian and Santonian at Site 258 (Naturaliste Plateau).

Figures 1-6 Archaeoglobigerina bosquensis Pessagno, Coniacian. Magnification $\times 120$.

$1,5,6$. Sample 258-7-3, 115-119 cm.

2-4: Sample 258-7-1, 121-125 cm.

Figures 7-13 Whiteinella baltica Douglas and Rankin, Santonian. Magnification $\times 160$.

Sample 258A-9-3, 132-134 cm.

Figures 14-16 Schackoina aff. cenomana (Schacko), Santonian. Magnification $\times 120$.

Sample 9-3, 132-134 cm. 
PLATE 5

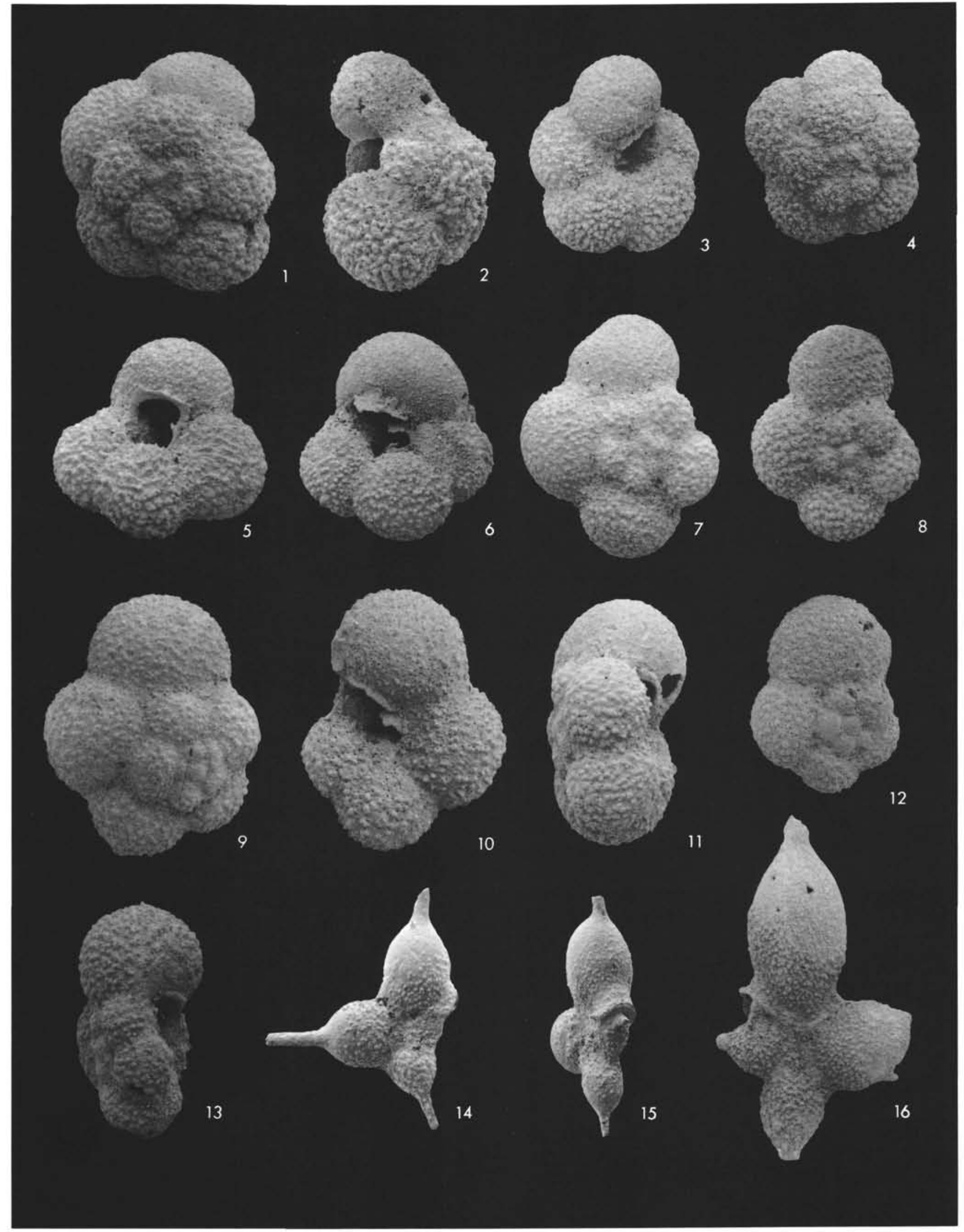




\section{PLATE 6}

Turonian-Santonian at Site 258. Magnification $\times 80$.

Figures 1-3 Praeglobotruncana algeriana Caron, Turonian, Core 13 , Sections 3 and 4.

Figure 4 Praeglobotruncana hagni Scheibnerova, Turonian. Core 13 , Sections 3 and 4 .

Figures 5-8 Globotruncana tricarinata (Quereau), Santonian.

5. Sample 258A-9, CC.

6, 7. Sample 258A-9-3, $132-134 \mathrm{~cm}$.

8. Sample 258A-9-6, 20-25 cm.

Figures 9-12 Globotruncana lapparenti Brotzen.

9. Santonian. Sample 258A-9, CC.

10, 11. Coniacian. Sample 258-7-3, 115-119 cm.

12. Santonian. Sample 258A-9-6, 20-25 cm.

Figures 13-15 Globotruncana coronata (Bolli).

13, 14. Coniacian. Sample 258-10-2, 53-57 cm.

15. Santonian. Sample 258A-9-1, 134-138 cm.

Figure 16 Globotruncana cretacea (d'Orbigny), Coniacian. Sample 258-7-1, 121-125 cm. 


\section{PLATE 6}
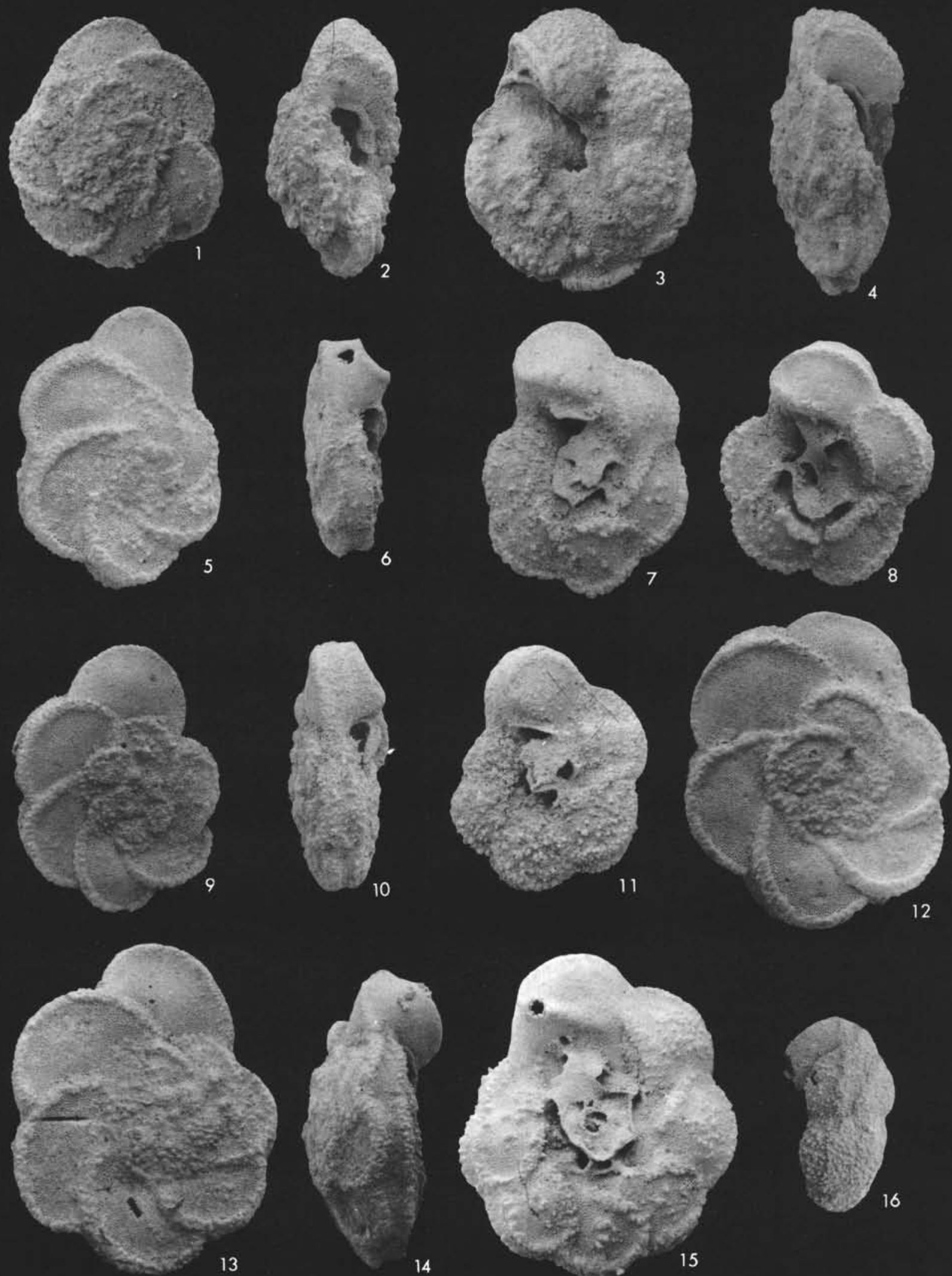


\section{PLATE 7}

Coniacian-Santonian at Site 258. Magnification $\times 80$.

Figures 1-10 Globotruncana sp. aff. ventricosa (White), Santonian.

$1,5,8,9$. Sample 258A-8, CC.

$2 ; 4,6,10$. Sample 258A-9-3, 132-134 cm.

3. Sample 258 A -9 , CC.

7. Sample 258A-8-6, 141-144 cm.

(Figures 6 and 7 show transitional forms to Globotruncana coronata [Bolli].)

Figure 11 Globotruncana angusticarinata (Gandolfi), Santonian. Sample 258A-9-3, 132-134 cm.

Figures 12-14 Globotruncana marginata (Reuss), Coniacian. Sample 258-7-3, 115-119 cm.

Figures 15-16 Globotruncana fornicata manaurensis Gandolfi, Santonian.

15. Sample 258A-9-1, $134-138 \mathrm{~cm}$.

16. Sample $258 \mathrm{~A}-8, \mathrm{CC}$. 


\section{PLATE 7}

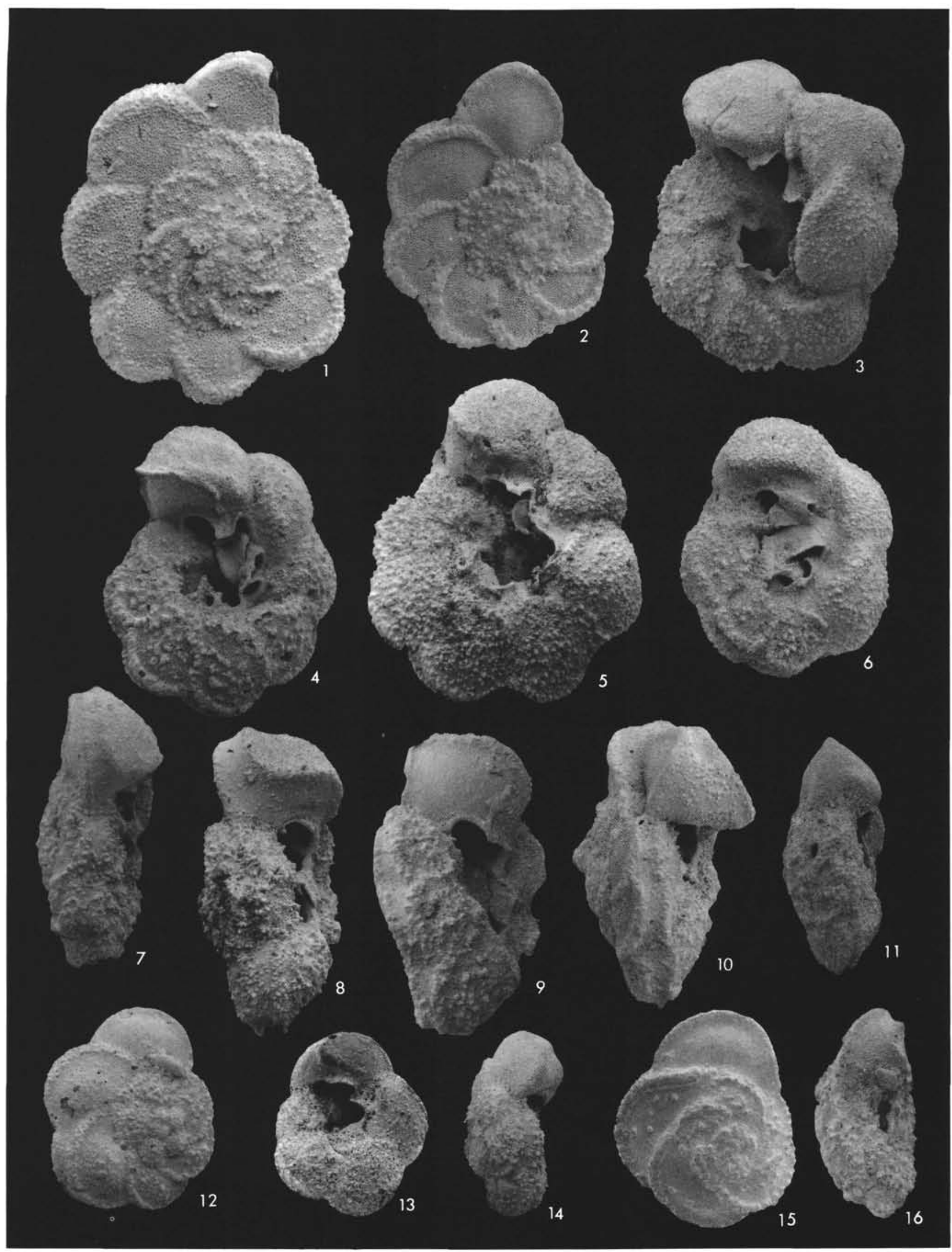

